\title{
Influence of Schistosoma mansoni infection on the reproductive capacity of albino mice
}

\author{
Influência da infecção pelo Schistosoma mansoni na capacidade \\ reprodutiva de camundongos albinos \\ Romulo Teixeira Mello, Cristina Hueb Barata, Paulo \\ Marcos Zech Coelho e Aluízio Prata
}

\begin{abstract}
This paper reports reduction on the reproductive capacity of female mice infected with Schistosoma mansoni, either in the acute phase or in the chronic one of the disease. This decrease in the reproductive capacity was highly significant $(93.3 \%$ and $86.7 \%$, for the acute and chronic phases, respectively).
\end{abstract}

Key-words: Schistosoma mansoni. Mice. Reproduction. Pregnancy.

Resumo Este trabalho trata de redução na capacidade reprodutiva de camundongos fêmeas infectados com Schistosoma mansoni, tanto na fase aguda como na fase crônica da doença. Esta diminuição da capacidade reprodutiva foi altamente significativa, com índices de 93,3\% e 86,7\% nas fases aguda e crônica, respectivamente.

Palavras-chave: Schistosoma mansoni. Camundongos. Reprodução. Gravidez.

Departamentos de Análises Clínicas e Toxicológicas da Faculdade de Farmácia e de Parasitologia do Instituto de Ciências Biológicas da Universidade Federal de Minas Gerais, Belo Horizonte, MG e Faculdade de Medicina do Triângulo Mineiro, Uberaba, MG.

Trabalho financiado por CNPq, FAPEMIG.

Endereço para correspondência: Prof. Paulo Marcos Zech Coelho. Departamento de Parasitologia/ICB/UFMG. Caixa Postal 486, 30161-970 Belo Horizonte, MG, Brasil.

Recebido para publicação em 22/12/97. 
There are hundreds of publications dealing with the affirmative that schistosomiasis is able to affect some organs of the reproductive system in females, these damages being caused by Schistosoma haematobium (Feldmeier et al, 1995). There is no doubt that the localization of this species in the vesical plexus facilitates the access of eggs up to the genito-urinary system. As far S. mansoni is concerned, there are some reports showing lesions on female genital organs caused by the parasite's eggs. Recently, Feldmeier et al (1997) report that 6 to $27 \%$ of women bearing intestinal schistosomiasis present, at least temporarily, some kind of pathology in their reproductive system. Amano et al (1990) described the consequences of schistosomiasis mansoni in the reproduction of mice. In this study, the authors detected reduction of $43.0 \%$ in the reproductive capacity of females, when the animals were observed in the acute phase. The present work aims at corroborating the findings concerning this subject in the literature, as well as adding new aspects observed that show alteration in the reproductive capacity of female mice infected in both acute and chronic phases of the disease, the chronic phase being studied for the first time. For this purpose, a group of female outbred albino mice was infected with $20 \mathrm{~S}$. mansoni cercariae (LE strain, Belo Horizonte, Brazil), by transcutaneous route. Sixty days later (acute phase), stool examinations were carried out in order to detect infection. This infected group, as well as a control group (15 animals), that was not infected with cercariae, were mated at the proportion of I male for 3 females. From the 21st day after mating onwards, it was observed fecundation in all females of the uninfected group, that gave birth to offsprings with normal development, whereas in the infected group only one female $(6.7 \%)$ was found to be pregnant, and gave birth to offsprings with clearly lower development, when compared to those of the control group. After parturition, a rest interval was observed up to the 130th day after infection (chronic phase), when mating was repeated. Then, it was again observed that all females of the uninfected group were pregnant, and their offsprings presented normal development, whereas only two infected females $(13.3 \%)$ were pregnant, and the development of their offsprings was marked lower. The results showed reduction of $93.3 \%$ and $86.7 \%$ in the reproductive capacity of infected animals in the acute and chronic phases, respectively. These data corroborate the findings of Amano et al (1990), besides showing continuity of this phenomenon in the chronic phase. Further, it could be detected some reduction in the percentage of procriation much more significant than that recorded by those authors. Probably, this phenomenon is related to an ectopic localization of granulomas caused by $S$. mansoni eggs in the organs of the reproductive system of those animals, producing as a result some hormonal alterations.

\section{REFERÊNCIAS BIBLIOGRÁFICAS}

1. Amano T, Freeman Jr GL, Colley DG. Reduced reproductive efficiency in mice with schistosomiasis mansoni and uninfected pregnant mice injected with antibodies with antibodies against Schistosoma mansoni egg antigens. American Journal of Tropical Medicine and Hygiene 43:180-185, 1990.

2. Feldmeier H, Poggensee G, Krantz I, Helling-Giese G. Female genital schistosomiasis. New challenges from a gender perspective. Tropical and Geographical Medicine 47 (suppl 2):15, 1995.

3. Feldmeier H, Dacal RC, Martins MJ, Soares VL, Martins R. Genital manifestations of schistosomiasis mansoni on women: important but neglected. In: Programme of VI International Symposium on Schistosomiasis, Belo Horizonte, p. 47, 1997. 